\title{
Evaluation of the antiproliferative activity of red propolis hydroalcoholic extract and its fractions obtained by partition
}

\author{
IARA SILVA SQUARISI ${ }^{1, *}$, KAROLINE SOARES DE FREITAS ${ }^{1, *}$, DANIELI CRISTINA LEMES ${ }^{1}$, \\ GARI VIDAL CCANA-CCAPATINTA ${ }^{2}$, JENNYFER ANDREA ALDANA MEJÍA ${ }^{2}$, JAIRO KENUPP BASTOS ${ }^{2}$, \\ RODRIGO CASSIO SOLA VENEZIANI ${ }^{1}$, SERGIO RICARDO AMBROSIO ${ }^{1}$, DENISE CRISPIM TAVARES ${ }^{1, \bullet}$ \\ ${ }^{1}$ Universidade de Franca. Avenida Dr. Armando Salles de Oliveira, 201, 14404-600, Franca, São Paulo, Brazil. \\ Tel.: +55-16-3711-8871; Fax: +55-16-3711-8878, ^email: denisecrispim2001@ yahoo.com \\ ${ }^{2}$ School of Pharmaceutical Sciences of Ribeirão Preto, University of São Paulo. Av. do Café, s/n, 14040-903, Ribeirão Preto, São Paulo, Brazil \\ *These authors contributed equally to this work.
}

Manuscript received: 13 January 2020. Revision accepted: 10 July 2020.

\begin{abstract}
Squarisi IS, De Freitas KS, Lemes DC, Ccana-Ccapatinta GV, Mejia JAA, Bastos JK, Veneziani RCS, Ambrosio SR, Tavares DC. 2020. Evaluation of the antiproliferative activity of red propolis hydroalcoholic extract and its fractions obtained by partition. Biofarmasi J Nat Prod Biochem 18: 70-73. The present study aimed to evaluate the cytotoxicity of red propolis hydroalcoholic extract (RPHE) and its fractions obtained by partition, hexanes (HF), dichloromethane (DF), ethyl acetate (AF), and $n$-butanol (BF) on tumor and non-tumor cell lines. For this purpose, the XTT colorimetric assay was performed on human lung fibroblasts (GM07492A, nontumor cell), breast adenocarcinoma (MCF-7), glioblastoma (U343), and cervix adenocarcinoma (HeLa) cells. The results showed that RPHE, HF, and DF presented not only cytotoxic potential to all tumor cell lines but also to normal cell lines, indicating selectivity absence. HF presented the lowest IC 50 (half minimal inhibitory concentration; 33.8-133.3 $\mu \mathrm{g} / \mathrm{mL}$ ), with a significant difference from those observed for RPHE $(137.0-262.7 \mu \mathrm{g} / \mathrm{mL})$. BF and AF revealed an $\mathrm{IC}_{50}$ higher than $1250 \mu \mathrm{g} / \mathrm{mL}$ in all cell lines. The results showed that red propolis has substances with antiproliferative activity, indicating that its hexane fraction may have substances with antitumor potential.
\end{abstract}

Keywords: cytotoxicity, red propolis, XTT colorimetric assay

\section{INTRODUCTION}

Propolis is a product of honeybee hives, containing mainly beeswax and a resin obtained from various plant sources such as apical buds, young leaves, and exudates (Salatino \& Salatino 2018). Red propolis, with Dalbergia ecastaphyllum (Daugsch et al., 2008; Silva et al., 2008) and Symphonia globulifera (Ccana-Ccapatinta et al., 2020) as its main botanical sources, has recently stood out as a natural medicinal product due to its various biological properties such as anti-inflammatory (Batista et al. 2018), antitumoral (Salatino \& Salatino 2018) antioxidant, cytotoxic (de Oliveira Reis et al., 2019), antimicrobial (Miranda et al. 2019) activities and healing capacity (Picolotto et al. 2019). The biological activity of red propolis is mainly related to isoflavones, which act in synergy with the other compounds. Other compounds, such as vestitol, neovestitol, biochanin A, and liquiritigenin, are identified in the fractions. The extracts of Brazilian red propolis are also considered important markers associated with different biological factors' effects (Rufatto et al., 2018; Nani et al., 2018).

Bio-guided fractionations are efficient methods to improve the development of new drugs, highlighting the activity of each group of compounds, individually or in combination with others (Dos Santos et al., 2019). Thus, the present study aimed to evaluate the cytotoxicity of the red hydroalcoholic extract (RPHE) and its fractions, namely, hexanic (HF), dichloromethane (DF), ethyl acetate (AF), and $n$-butanol (BF), on tumor and non-tumor cell lines.

\section{MATERIALS AND METHODS}

Obtention and profiling of red propolis hydroalcoholic extract (RPHE) and its fractions

Red propolis $(2 \mathrm{~kg})$ was purchased from Cooperativa de apicultores de Canavieiras (COAPER) in the city of Canavieiras (Bahia state, Brazil,) in April of 2018. RPHE was prepared by exhaustive maceration of $500 \mathrm{~g}$ of red propolis in 1.5 L of ethanol: $\mathrm{H}_{2} \mathrm{O}(7: 3 \mathrm{v} / \mathrm{v})$ for seven days. The extract was then filtered, concentrated, and lyophilized to result in $75 \mathrm{~g}$ of RPHE. After resuspending RPHE in 500 mL of methanol: $\mathrm{H}_{2} \mathrm{O}(8: 2 \mathrm{v} / \mathrm{v})$, the fractioning of this extract was executed through a four-times partition with $500 \mathrm{~mL}$ of hexanes, dichloromethane, ethyl acetate, and $n$ butanol respectively to result in $\mathrm{HF}(22.8 \mathrm{~g})$, DF (43.6g), $\mathrm{AF}(0.90 \mathrm{~g})$, and $\mathrm{BF}(4.34 \mathrm{~g})$ after evaporation.

The chemical profiles of RPHE and its fractions were obtained by HPLC-DAD analysis using a Synergi Polar-RP $(150 \times 4.60 \mathrm{~mm}, 4 \mu \mathrm{m})$ column as a stationary phase and a mobile gradient phase of $\mathrm{H}_{2} \mathrm{O}$ (A) and acetonitrile (B) starting from $23 \%$ up to $100 \%$ of (A) in $32 \mathrm{~min}$ at 1.2 $\mathrm{mL} / \mathrm{min}$. The detection wavelength was $220 \mathrm{~nm}$, and the identification of the compounds was performed by co- 
injection of standard concentrations available in our laboratory (Figure 1): liquiritigenin (1), formononetin (2), liquiritigenin (3), vestitol (4), neovestitol (5), medicarpin (6), 7-O-methylvestitol (7), a mixture of guttiferone E and xanthochymol (8), oblongifolin B (9).

\section{Evaluation of antiproliferative activity}

In this study, three different tumor cell lines were used: human breast adenocarcinoma (MCF-7), human cervical adenocarcinoma (HeLa), and human glioblastoma (U343). A normal human cell line (lung fibroblasts, GM07492A) was included to evaluate the possible selective activity of the natural medicinal product under investigation. Different cell lines were maintained as monolayers in plastic culture medium (HAM-F10 + DMEM, 1:1, Sigma-Aldrich) supplemented with $10 \%$ fetal bovine serum (Nutricell), antibiotics $(0.01 \mathrm{mg} / \mathrm{mL}$ streptomycin and $0.005 \mathrm{mg} / \mathrm{mL}$ penicillin; Sigma-Aldrich) and $2.38 \mathrm{mg} / \mathrm{mL}$ HEPES (Sigma-Aldrich). Cells were incubated at $36.5^{\circ} \mathrm{C}$ in humidified $5 \% \mathrm{CO}_{2}$ atmosphere.

According to the manufacturer's guidelines, the samples' antiproliferative activity was evaluated using the in vitro toxicology colorimetric assay-XTT Kit (Roche Diagnostics). For the experiments, 1 x $10^{4}$ cells were seeded in 96-well microplates; each well received a maximum of $100 \mu \mathrm{L}$ culture medium (HAM F10 + DMEM, 1:1) supplemented with 10\% fetal bovine serumcontaining different sample concentrations, which ranged 9.77 to $1250 \mu \mathrm{g} / \mathrm{mL}$. Negative (untreated), solvent $(1 \%$ DMSO), and positive (25\% DMSO) control wells were also included. After incubation with the substances at 37 ${ }^{\circ} \mathrm{C}$ for $24 \mathrm{~h}$, the culture medium was removed, and the cells were washed with $100 \mu \mathrm{L}$ PBS to remove treatments and exposed to $100 \mu \mathrm{L}$ HAM-F10 culture medium without phenol red. Then, $25 \mu \mathrm{L}$ of XTT were added to each well, and the microplates were incubated at $37^{\circ} \mathrm{C}$ for $17 \mathrm{~h}$. The absorbance of the samples was determined using a multiplate reader (Asys-UVM 340/Microwin 2000 ELISA) at a wavelength of $450 \mathrm{~nm}$ and a reference length of $620 \mathrm{~nm}$. The number of soluble products formed (formazan) was proportional to the number of viable cells. The negative control group was designated as $100 \%$, and the results were expressed as a percentage of the negative control. The experiments were performed in triplicate.

\section{Statistical analysis}

Cytotoxicity was assessed using the $\mathrm{IC}_{50}$ value $(50 \%$ cell growth inhibition) as a response parameter, calculated with the GraphPad Prism 5.0 program (GraphPad Software, San Diego, CA, USA), plotting cell survival against the respective concentrations of the natural products tested. One-way ANOVA was used to compare means $(p<0.05)$.

\section{RESULTS AND DISCUSSION}

\section{Results}

Table 1 presents the results expressed by the inhibitory concentration of $50 \%$ cell growth $\left(\mathrm{IC}_{50}\right)$. The results showed that, for each cell line-GM07492A (human lung fibroblasts, non-tumor cells), MCF-7 (breast adenocarcinoma), U343 (glioblastoma), and HeLa (cervix adenocarcinoma)-RPHE revealed an $\mathrm{IC}_{50}$ of 137.0, 262.7, 138.2 and $137.4 \mu \mathrm{g} / \mathrm{mL}, \mathrm{HF}$ an $\mathrm{IC}_{50}$ of $33.8,133.3,33.8$ and $34.5 \mu \mathrm{g} / \mathrm{mL}$, DF an $\mathrm{IC}_{50}$ of $78.9,237.6,71.6$ and 99.6 $\mu \mathrm{g} / \mathrm{mL}$, and $\mathrm{AF}$ and BF an $\mathrm{IC}_{50}$ of higher than $1250 \mu \mathrm{g} / \mathrm{mL}$ in all cell lines. RPHE, HF, and DF, therefore, showed cytotoxic activity in all tumor cell lines and the normal cell line, indicating selectivity absence. HF presented the highest cytotoxic potential with the lowest $\mathrm{IC}_{50}$, being significantly different from those observed for RPHE. The cytotoxicity of HF might be attributed to its chemical composition, consisting predominantly of polyprenylated benzophenones 8 and $\mathbf{9}$ (guttiferone E, xanthochymol, and oblongifolin B), described in the literature as pro-apoptotic compounds.

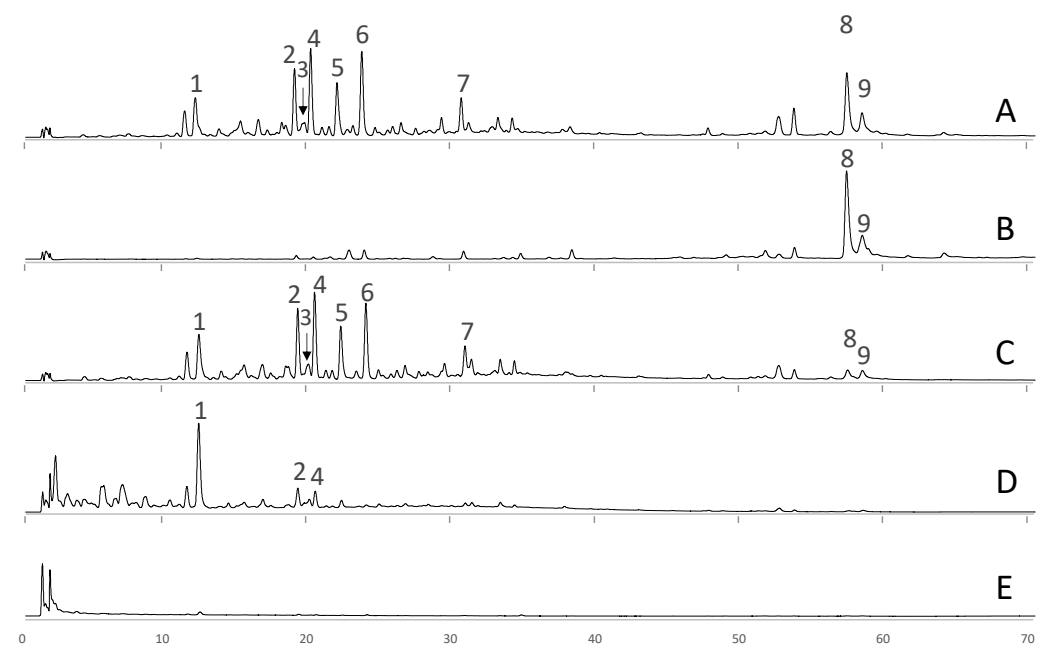

Figure 1. HPLC-DAD profile of red propolis hydroalcoholic extract (RPHE; A) and its fractions obtained in $n$-hexanes (HF; B), dichloromethane (DF; C), ethyl acetate (AF; D), and $n$-butanol (BF; E). Identity of main constituents: liquiritigenin (1), formononetin (2), liquiritigenin (3), vestitol (4), neovestitol (5), medicarpin (6), 7-O-methylvestitol (7), a mixture of guttiferone E and xanthochymol (8), oblongifolin B (9) 
Table 1. Inhibitory concentrations ( $\mathrm{IC}_{50}, \mu \mathrm{g} / \mathrm{mL}$ ) obtained from RPHE-treated non-tumoral (GM07492A) and tumoral (MCF-7, U343 and $\mathrm{HeLa}$ ) cell cultures and its fractions.

\begin{tabular}{lcccc}
\hline \multirow{2}{*}{ Treatment } & \multicolumn{4}{c}{ Cell line } \\
\cline { 2 - 5 } & GM07492A & MCF-7 & U343 & HeLa \\
\hline RPHE & $137.0 \pm 4.2$ & $262.7 \pm 5.9$ & $138.2 \pm 2.3$ & $137.4 \pm 0.3$ \\
HF & $33.8 \pm 0.6^{\mathrm{a}}$ & $133.3 \pm 1.3^{\mathrm{a}}$ & $33.8 \pm 0.3^{\mathrm{a}}$ & $34.5 \pm 0.1^{\mathrm{a}}$ \\
DF & $78.9 \pm 17^{\mathrm{a}}$ & $237.6 \pm 26.6$ & $71.6 \pm 0.6^{\mathrm{a}}$ & $99.6 \pm 27.3$ \\
AF & $>1250$ & $>1250$ & $>1250$ & $>1250$ \\
BF & $>1250$ & $>1250$ & $>1250$ & $>1250$ \\
\hline
\end{tabular}

Note: RPHE: red propolis hydroalcoholic extract; HF: hexanes fraction; DF: dichloromethane fraction; AF: ethyl acetate fraction; BF: $n$ butanol fraction. GM07492A: non-tumor human lung fibroblast; MCF-7: human breast adenocarcinoma; U343: human glioblastoma; HeLa: human cervical adenocarcinoma. Values are mean \pm SD, n: 3. a Significantly different from the RPHE treatment $(p<0.05)$

\section{Discussion}

In this sense, Lin et al. (2019) reported cytotoxicity of a mixture of guttiferone $\mathrm{E}$ and xanthochymol in five types of human cancer cell lines: leukemic $\left(\mathrm{HEL}, \mathrm{IC}_{50}=11.27\right.$ $\left.\mu \mathrm{g} / \mathrm{mL} ; \mathrm{K} 562, \mathrm{IC}_{50}=10.92 \mu \mathrm{g} / \mathrm{mL}\right)$, cervical $\left(\mathrm{HeLa}, \mathrm{IC}_{50}=\right.$ $5.46 \mu \mathrm{g} / \mathrm{mL}$ ), breast (MCF-7, $\mathrm{IC}_{50}=4.68 \mu \mathrm{g} / \mathrm{mL}$ ) and lung (A549, $\mathrm{IC}_{50}=6.10 \mu \mathrm{g} / \mathrm{mL}$ ). These results demonstrate that these two substances present in the hexanes fraction of red propolis corroborate their cytotoxic potential.

Novak et al. (2017) observed that a fraction of the ethanolic extract of Brazilian red propolis, containing xanthochymol and formononetin, showed an antiproliferative effect in acute promyelocytic leukemia cell lines (HL-60, $\mathrm{IC}_{50}=20.5 \mu \mathrm{g} / \mathrm{mL}$ ), human chronic myeloid leukemia $\left.(\mathrm{K} 562) . \mathrm{IC}_{50}=30.3 \mu \mathrm{g} / \mathrm{mL}\right)$, multiple myeloma (RPMI8226, IC I0 $_{50}=32.6 \mu \mathrm{g} / \mathrm{mL}$ ) and murine melanoma $\left(\mathrm{B} 16 \mathrm{~F} 10, \mathrm{IC}_{50}=25.7 \mu \mathrm{g} / \mathrm{mL}\right)$. The fraction showed a more promising antiproliferative effect than that observed by the ethanolic extract.

Through the MTT test, the ethyl acetate fractions of the red propolis extract revealed cytotoxic activity in HT-29 (human colorectal adenocarcinoma) and HCT-116 (human colorectal carcinoma), and non-tumor cell line Vero (monkey kidney epithelium). $\mathrm{IC}_{50}$ values ranged from 40.32 to $105.23 \mu \mathrm{g} / \mathrm{mL}$, with the lowest $\mathrm{IC}_{50}$ values corresponding to the tumoral lines tested, indicating selectivity. Chemical analysis of the fractions indicated the presence of formononetin, vestitol, biochanin A, liquiritigenin, and the guttiferone $\mathrm{E}$ xanthochymol mixture (Santos et al., 2019).

The antiproliferative activity of the hydroethanolic extract of red propolis and two of its fractions $(\mathrm{J}$ and $\mathrm{L})$ was evaluated in human laryngeal epidermoid carcinoma cells (Hep-2) by Da Silva Frozza et al. (2017). The chemical profile of fraction $\mathrm{J}$ revealed the presence of formononetin, liquiritigenin, medicarpin, vestitol, isovestitol, and (3S)-ferreirin, and fraction L, only fraction $\mathrm{L}$ liquiritigenin. The results showed an $\mathrm{IC}_{50}$ of 145.40 $\mu \mathrm{g} / \mathrm{mL}$ for the extract, $60.96 \mu \mathrm{g} / \mathrm{mL}$ for the J fraction, and $74.60 \mu \mathrm{g} / \mathrm{mL}$ for the $\mathrm{L}$ fraction. Thus, the fractions showed a greater cytotoxic effect than the extract. Fractionation of the extract leads to a decrease in the number of chemicals present in the fraction. It may increase the concentration of active compounds compared to the exposure of cells to the crude extract (da Silva Frozza et al., 2017).
The results showed that red propolis presents substances with antiproliferative activity, indicating that the hexane fraction may have substances with antitumor potential. Further studies should be conducted with guttiferone $\mathrm{E}$, xanthochymol, and oblongifolin $\mathrm{B}$, substances predominantly identified in the hexane fraction.

\section{ACKNOWLEDGEMENTS}

This work was supported by the São Paulo Research Foundation (FAPESP, Brazil; grants \#2016/24269-7 and \#2017/04138-8) and Coordination for the Improvement of Higher Education Personnel (CAPES, Brazil). K.S. Freitas was the recipient of a master's fellowship from FAPESP (grants \#2018/02370-3). The authors are grateful to the National Council for Scientific and Technological Development (CNPq, Brazil) for the fellowships granted. The authors declare that there is no conflict of interest.

\section{REFERENCES}

Batista CM, Alves AVF, Queiroz LA, Lima BS, Araújo AAS, de Albuquerque Júnior RLC, Cardoso JC. 2018. The photoprotective and anti-inflammatory activity of red propolis extract in rats. J Photochem Photobiol B 180: 198-207.

Ccana-Ccapatinta GV, Mejía JAA, Tanimoto MH, Groppo M, Carvalho JCAS, Bastos JK. 2020. Dalbergia ecastaphyllum (L.) Taub. and Symphonia globulifera L.f.: The botanical sources of isoflavonoids and benzophenones in Brazilian red propolis. Molecules 25 (9): 2060.

Frozza CODS, Santos DA, Rufatto LC, Minetto L, Scariot FJ, Echeverrigaray S, Pich CT, Moura S, Padilha FF, Borsuk S, Savegnago L, Collares T, Seixas FK, Dellagostin O, Roesch-Ely M, Henriques JAP. 2017. Antitumor activity of Brazilian red propolis fractions against Hep-2 cancer cell line. Biomed Pharmacother 91: 951-963.

Daugsch A, Moraes CS, Fort P, Park YK. 2008. Brazilian red propolischemical composition and botanical origin. Evid Based Compl Altern Med 5 (4): 435-441

de Oliveira Reis JH, de Abreu Barreto G, Cerqueira JC, dos Anjos JP, Andrade LN, Padilha FF, Druzian JI, Machado BAS. 2019. Evaluation of the antioxidant profile and cytotoxic activity of red propolis extracts from different regions of northeastern Brazil obtained by conventional and ultrasound-assisted extraction. PloS One. 14: e0219063. DOI: 10.1371/journal.pone.0219063.

dos Santos DA, Munari FM, da Silva Frozza CO, Moura S, Barcellos T, Henriques JAP, Roesch-Ely M. 2019. Brazilian red propolis extracts: study of chemical composition by ESI-MS/MS (ESI+) and cytotoxic 
profiles against colon cancer cell lines. Biotechnol Res Innov 3: 120130.

Lin X, Tian D, Fu Y, Li Y, Huang L, Gu W, Song J, Li Y, Ben-David Y, Wen M, Yuan C, Hao X. 2019. Synthesis of novel guttiferone E and xanthochymol derivatives with cytotoxicities by inducing cell apoptosis and arresting the cell cycle phase. Eur J Med Chem 162: 765-780.

Miranda SLF, Damasceno JT, Faveri M, Figueiredo L, da Silva HD, Alencar SMDA, Rosalen PL, Feres M, Bueno-Silva, B. 2019. Brazilian red propolis reduces orange-complex periodontopathogens growing in multispecies biofilms. Biofouling. 35 (3): 308-319.

Nani BD, Franchin M, Lazarini JG, Freires IA, da Cunha MG, BuenoSilva B, de Alencar SM, Murata RM, Rosalen PL. 2018. Isoflavonoids from Brazilian red propolis down-regulate the expression of cancer-related target proteins: A pharmacogenomic analysis. Planet Sci J 32: 750-754.

Novak EM, Silva MSC, Marcucci MC, Sawaya ACHF, López BGC, Fortes MAHZ, Giorgi RR, Marumo KT, Rodrigues RF, Maria DA. 2014. Antitumoural activity of Brazilian red propolis fraction enriched with xanthochymol and formononetin: An in vitro and in vivo study. J Funct Foods 11: 91-102.

Picolotto A, Pergher D, Pereira GP, Machado KG, da Silva Barud $\mathrm{H}$, Roesch-Ely M, Gonzalez MH, Tasso L, Figueiredo JG, Moura, S. 2019. Bacterial cellulose membrane associated with red propolis as phytomodulator: Improved healing effects in experimental models of diabetes mellitus. Biomed Pharmacother 112: 108640. DOI: 10.1016/j.biopha.2019.108640.

Rufatto LC, Luchtenberg P, Garcia C, Thomassigny C, Bouttier S, Henriques JAP, Roesch-Ely M, Dumas F, Moura S. 2018. Brazilian red propolis: Chemical composition and antibacterial activity determined using bioguided fractionation. Microbiol Res 214: 74-82.

Salatino A, Salatino MLF. 2018. Brazilian red propolis: legitimate name of the plant resin source. MOJ Food Process Technol 6 (1): 1-3. DOI: 10.15406/mojfpt.2018.06.00139

Teixeira ÉW, Negri G, Meira RMSA, Message D, Salatino A. 2005. Plant origin of green propolis: bee behavior, plant anatomy and chemistry. Evid-Based Compl Altern Med 2 (1): 85-92. DOI: 10.1093/ecam/neh055. 